\title{
PENINGKATAN EKONOMI PETERNAK SAPI MELALUI DIGITALISASI DATA DENGAN BARCODE
}

\author{
IMPROVING THE ECONOMY OF COW BREEDERS THROUGH DATA DIGITALIZATION BY \\ USING BARCODE
}

\author{
${ }^{1)}$ Eko Arief Cahyono, ${ }^{2)}$ Zumrotul Fauziah, ${ }^{3)}$ Nurul Huda, ${ }^{4)}$ Sunu Wahyudi, ${ }^{5)}$ Risalatul \\ Hasanah \\ Universitas Nahdlatul Ulama Sunan Giri Bojonegoro \\ Email: zumrotulfauziah@ sunan-giri.ac.id
}

\begin{abstract}
Salah satu upaya untuk meningkatkan ekonomi kelompok peternak Sekolah Ternak Rakyat (SPR) Mega Jaya Dusun Ngantru Kecamatan Kasiman dimasa pandemi covid 19 adalah dengan melakukan pendampingan melalui digitalisasi data dengan Barcode. Tujuan pengabdian masyarakat ini yang pertama adalah mengenalkan dan mempraktekkan teknologi yang bisa dimanfaatkan untuk meningkatkan pola manajemen data dan pemasaran sapi sehingga angka penjualan sapi bisa naik dan pendapatan para peternak sapi meningkat. Yang kedua untuk memudahkan calon pembeli dan pengunjung SPR Mega Jaya mendapatkan informasi data secara cepat dan akurat tanpa harus bertemu dengan pemiliknya. Metode Pemberdayaan yang digunakan adalah menggunakan metode ABCD (Asset Based Community Development) dengan mengutamakan potensi dan pemanfaatan aset yang ada di sekitar masyarakat Dusun Ngantru Kecamatan Kasiman. Hasil dari digitalisasi dengan barcode yang pertama adalah meningkatnya penjualan sapi kelompok peternak SPR Mega jaya dimasa pandemi dibandingkan sebelum menggunakan sistem Barcode. Yang kedua memudahkan pengelola kelompok ternak untuk memberikan informasi data sapi secara cepat dan akurat kepada calon pembeli dan pengunjung. Yang Ketiga adanya kepedulian pemuda karang taruna Dusun Ngantru untuk menjadi kader \& relawan IT Kelompok ternak SPR Mega Jaya, dan yang keempat meningkatkan pola manajemen data dan pemasaran sapi berbasis IT.
\end{abstract}

Kata kunci : Digitalisasi, Barcode, Pendampingan, SPR

\section{PENDAHULUAN}

Pandemi Covid-19 memberikan dampak yang luar biasa di berbagai sektor kehidupan, mulai dari kesehatan, perekonomian, pendidikan, pariwisata, pertanian, sosial, peternakan, dan sektor-sektor lainnya. Di tengah pendemi, beberapa aktifitas bisa dilakukan dari rumah secara on-line (daring), namun beberapa aktifitas lainnya tetap harus dilakukan di luar rumah dengan menerapkan protokol kesehatan seperti menggunakan masker, mencuci tangan, dan menjaga jarak untuk mencegah penularan virus Covid-19. Adanya Covid-19 membatasi gerak langkah seluruh masyarakat dunia untuk beraktifitas seperti sebelumnya dan menyebabkan penurunan yang cukup 
signifikan di beberapa sektor, diantaranya yang sangat terlihat, yaitu di bidang ekonomi dan pendidikan. Berkaitan dengan hal tersebut, perlu adanya kegiatan pengabdian kepada masyararakat yang memberikan edukasi kepada masyarakat tentang pencegahan Covid-19 dan upaya peningkatan ekonomi masyarakat di masa pandemi.

Kegiatan pengabdian kepada masyarakat ini dilakukan di Dusun Ngantru, Desa Sekaran Kecamatan Kasiman Kabupaten Bojonegoro. Dusun Ngantru merupakan dusun yang cukup sulit untuk dijangkau karena berada di rute jalan yang masih berbatu dan melewati hutan. Karena lokasinya yang sulit untuk dijangkau menjadikannya sebagai Dusun isolasi mandiri di Desa Sekaran. Dusun Ngantru berbatasan dengan Desa Wonocolo dan Desa Mayang di sebelah utara, Desa Besah di sebelah barat, Desa Tambak Merak di sebelah Selatan, dan Desa Kawengan di sebelah Timur. Jarak Dusun Ngantru dari Desa Sekaran $6 \mathrm{~km}$. Jumlah warga yang ada di Dusun Ngantru sebanyak 2.378 jiwa penduduk. Dengan rincian laki-laki sebanyak 1.200 jiwa penduduk dan untuk perempuan sebanyak 1.178 jiwa penduduk. ${ }^{1}$

Mayoritas warga dusun Ngantru berprofesi sebagai petani dan peternak. Salah satu jenis tanaman yang banyak ditanam adalah Jagung. Hal ini dikarenakan kondisi geografis di sebagian besar wilayah dusun Ngantru yang berada di dataran tinggi. Sedangkan untuk tanaman padi, hanya bisa ditanam pada musin hujan karena belum adanya sistem pengairan atau irigasi di lahan pertanian yang ada. Jenis tanaman lain yang bisa ditemukan di dusun Ngantru yaitu kacang tanah, kacang hijau, dan tebu. Namun, tanaman-tanaman tersebut hanya ditanam pada musim-musim tertentu.

Selain lahan pertanian dan hutan yang luas, Dusun Ngantru juga memiliki sumber air bersih yang disebut dengan Sendang. Sumber mata air ini ditampung di bak penampungan dan disalurkan melalui pipa ke rumah-rumah warga. Selanjutnya, potensi lain yang ada di Dusun Ngantru adalah SPR (Sekolah Peternakan Rakyat). Sekolah Peternakan Rakyat merupakan salah satu program pemerintah dusun Ngantru yang bekerjasama dengan Lembaga Penelitian dan Pengabdian kepada Masyarakat (LPPM) Institut Pertanian Bogor (IPB) yang berhasil menjadi program nasional melalui Direktorat Jenderal Peternakan dan Kesehatan Hewan, dan Kementerian Pertanian Republik Indonesia. ${ }^{2}$ SPR yang ada di Dusun Ngantru Desa Sekaran Kecamatan Kasiman merupakan satu dari 3 SPR yang ada di Bojonegoro, dimana hal tersebut merupakan kegiatan nasional yang dikembangkan oleh IPB. Kepala SPR Dusun Ngantru adalah Kepala Dusun yaitu bapak Darwanto. Di SPR dusun Ngantru terdapat 200 ekor sapi. $^{3}$

Sebelumnya, sapi-sapi yang terdapat di SPR dusun Ngantru di data secara manual dengan cara pembukuan dan pelabelan. Pembukuan tersebut berisi data keseluruhan sapi yang terdapat di SPR. Pelabelan yang dimaksud adalah pemasangan label pada masing-masing sapi yang berisi kode. Masing-masing sapi diberikan kode khusus yang terdiri dari angka dan huruf. Kode tersebut dituliskan di sebuah media berbahan plastik berukuran $5 \times 7 \mathrm{~cm}$ dan ditempelkan di telinga kiri masing-masing sapi. Calon pembeli yang datang ke SPR kesulitan membaca kode yang ditempelkan ditelinga sapi karena kode tersebut hanya dimengerti oleh pengelola SPR. Sehingga pengelola harus menjelaskan maksud dari kode agar calon pembeli mengatahui data

\footnotetext{
${ }^{1}$ Darwanto, Kepala Dusun Ngantru, Wawancara, Warga Desa Sekaran, 6 April 2021.

${ }^{2}$ LPPM IPB, "SPR Bojonegoro", httpp;//LPPM.IPB.ac.id/?page_id=8100, diakses pada tanggal 7 April 2021 pukul 22.50 wib.

${ }^{3}$ Darwanto, Kepala Dusun Ngantru, Wawancara, Warga Desa Sekaran, 6 Maret 2021.
} 
sapi. Managemen data yang masih tradisional ini dapat menjadi penghambat berkembangnya perekonomian peternak. Ada beberapa faktor yang menjadi penghambat dalam meningkatkan ekonomi perternak sapi, antara lain manajemen peternakan relatif tradisional, sulitnya mendapatkan makanan ternak di saat musim kemarau dan para perternak yang kurang memperhatikan kebersihan kandang. 4

Di era digital ini, penggunaan kode angka dan huruf ini dianggap kurang efektif. Sehingga perlu adanya digitalisasi data sapi yang dapat diakses dengan cepat dan mudah. Kurangnya pengetahuan peternak sapi terhadap pemanfaatan teknologi menjadi penghambat tersendiri baik dalam pengelolaan data maupun pemasaran. Untuk itu, perlu adanya kemitraan antara akademisi dengan para peternak sapi. Dalam proses kemitraan tersebut, peternak dan akademisi bisa beersama-sama mempraktekkan teknologi yang bisa dimanfaatkan untuk meningkatkan pola manajemen data dan pemasaran. Sehingga, angka penjualan sapi bisa naik dan pendapatan para peternak sapi meningkat. ${ }^{5}$

Kegiatan pengabdian kepada masyarakat ini fokus pada bidang teknologi, yaitu digitalisasi data sapi dengan menggunakan Barcode. Barcode (kode batang) merupakan sekumpulan data optik yang diperuntukkan untuk dibaca mesin. Barcode diperoleh dari mengumpulkan data-data dalam lebar (garis) dan spasi garis parallel yang disebut sebagai kode batang atau simbologi linier atau 1D (1 dimensi). ${ }^{6}$ Program kerja pembuatan barcode sapi ini bertujuan untuk memudahkan pengunjung Sekolah Peternak Rakyat (SPR) untuk mengetahui data sapi dengan cepat. Barcode tersebut berisi tentang data pemilik, jenis, riwayat keturunan, jenis kelamin, berat sapi, dan lain-lain. Barcode sapi yang terpasang di badan sapi akan memudahkan calon pembeli yang datang, karena mereka tidak perlu bertemu langsung dengan pemilik sapi. Calon pembeli cukup memindai Barcode yang terpasang pada masing-masing sapi dengan menggunakan Smartphone, dan data bisa langsung terlihat.

\footnotetext{
4 Kartika Tribuana Dewi, 2013, Kemitraan Masyarakat Peternak Sapi Perah Dengan Kud "Batu" Dalam Meningkatkan Ekonomi Masyarakat Peternak Sapi Perah, Jurnal Administrasi Publik, Vol 1, No. 4 (2013)

${ }^{5}$ Sawitri, A. P., Ajiningrum, P. S., \& Suhardiyah, M. (2018). Peningkatan Ekonomi Peternak Sapi Perah dan Masyarakat Desa Melalui Diversifikasi Produk Olahan Dengan Bahan Baku Susu Sapi. JPM (Jurnal Pemberdayaan Masyarakat), 3(2), 272 - 278.

${ }^{6}$ Yudha Yudhanto, "Sejarah Teknologi Barcode", Ilmu Komputer.Com, (2003-2007), 3.
} 


\section{METODE}

Kegiatan pengabdian kepada masyarakat ini menggunakan metode ABCD (Asset Based Community Development) yang merupakan salah satu pendekatan yang sering digunakan dalam pendampingan masyarakat. Secara umum pengertian ABCD adalah pendekatan pengembangan masyarakat yang didasarkan pada asset lokal yang terdapat di suatu wilayah. Aset tersebut kemudian dikembangkan sehingga dapat memecahkan masalah-masalah yang terdapat diwilayah dimana proses pemberdayaan dilaksanakan. ${ }^{7}$ Dalam pendampingan menggunakan metode ABCD ini, pendamping mengutamakan aset dan potensi yang dimiliki masyarakat untuk selanjutnya digunakan sebagai bahan untuk pemberdayaan. ${ }^{8}$

Metodologi pendekatan menggunakan ABCD (Asset Based Community Development) mengutamakan potensi dan pemanfaatan aset yang ada di sekitar masyarakat. Metode ABCD ini terdiri dari 5 konsep utama sebagai analisis aset yang ada dalam masyarakat, yaitu: kapital manusia (SDM), kapital sosial (modal sosial), kapital fisik (Infrastruktur), kapital keuangan, dan kapital lingkungan (SDA). ${ }^{9}$ Dalam metode $\mathrm{ABCD}$ ini memiliki 5 langkah melakukan riset pendampingan diantaranya: Discovery (menemukan), Dream (Impian), Design (Merancang), Define (Menentukan), Destiny (Melakukan) ${ }^{10}$

Dalam kegiatan pengabdian ini, tim terlebih dahulu melakukan identifikasi dengan cara melakukan wawancara terhadap kepada dusun, tokoh masyarakat dan beberapa warga untuk mengetahui kondisi dan menemukan potensi yang ada di dusun Ngantru. Kemudian, tim melakukan analisis lebih mendalam mengenai salah satu potensi di dusun Ngantru yang ingin dikembangkan, yaitu Sekolah Peternakan Rakyat (SPR). Setelah proses identifikasi dilakukan, tim merancang program kegiatan dan bersama-sama masyarakat melaksanakan program yang telah ditetapkan.

\footnotetext{
7 Tim Penyusun KKN ABCD UNUGIRI Bojonegoro, Buku Pedoman Pelaksanaan KKN Universitas Nahdlatul Ulama Sunan Giri Bojonegoro, (Bojonegoro: LPPM UNUGIRI Bojonegoro, 2021), 22.

${ }^{8}$ Nurul Mahmudah "Pemberdayaan Pada Anak-Anak Gang Dolly di SMA Artantika dengan Metode Asset Based Community Development”, Madani, No.1, Vol. 1, (Desember, 2018) 17-29.

${ }^{9}$ Chika Riyanti dan Santoso Tri Raharjo, “Asset Based Community Development dalam Program Corporate Social Responsibility (CSR), Jurnal Kolaborasi Resolusi Konflik, No. 1, Vol. 3, (2021), 116.

${ }^{10}$ Christopher Dureau, Pembaru dan Kekuatan Lokal Untuk Pembangunan, Australian Community Development and Civil Society Strengthening Scheme (ACCES) Tahap II, (Agustus, 2013), 96-97.
} 


\section{HASIL DAN PEMBAHASAN}

\section{Pemasaran Sapi Peternak SPR Mega Jaya}

Komoditas yang dipasarkan oleh kelompok Sekolah Peternak Rakyat (SPR) Mega Jaya Dusun Ngantru berupa Sapi hasil penggemukan peranakan jenis Ongole dan Brahman cross serta bio gas dan olahan pupuk kandang (Kotoran Sapi). Ternak sapi hasil penggemukan dalam penjualannya dipasarkan dengan mengikuti mekanisme pasar tradisional yaitu dengan bantuan makelar sapi yang menawarkan sapi ternak SPR pada calon pembeli. Selain penjualan yang masih mengikuti mekanisme tradisional sapi-sapi yang terdapat di SPR Dusun Ngantru masih di data secara manual oleh peternak dengan cara pembukuan dan pelabelan. Pembukuan tersebut berisi data keseluruhan sapi yang terdapat di SPR yang meliputi Jenis Sapi, Keturunan Sapi, Berat Sapi, Jenis Kelamin, Usia Sapi, Reproduksi Sapi, Nama Pemilik sapi dan Alamat Pemilik sapi. Pelabelan yang dimaksud adalah pemasangan label pada masing-masing sapi yang berisi kode. Masing-masing sapi diberikan kode khusus yang terdiri dari angka dan huruf. Kode tersebut dituliskan di sebuah media berbahan plastik berukuran $5 \times 7 \mathrm{~cm}$ dan ditempelkan di telinga kiri masing-masing sapi. Calon pembeli yang datang ke SPR kesulitan membaca kode yang ditempelkan ditelinga sapi karena kode tersebut hanya dimengerti oleh pengelola SPR \& tulisanya yang kecil menyulitkan untuk dibaca. Sehingga pengelola harus menjelaskan maksud dari kode agar calon pembeli mengatahui data sapi, setelah pembeli tertarik untuk membelinya baru pengelola SPR mencari pemilik sapi untuk menentukan harga sapi yang akan di beli. Managemen data \& pemasaran yang masih tradisional ini dapat menjadi penghambat dalam meningkatkan perekonomian dan Kesejahteraan peternak SPR Dusun Ngantru. Beberapa faktor yang menjadi penghambat dalam meningkatkan ekonomi perternak sapi SPR, antara lain manajemen peternakan relatif tradisional sehingga pembeli tidak bisa leluasa untuk menggali informasi sapi yang akan dibeli, Lokasi ternak sapi SPR yang medanya cukup sulit dan Jauh, Pengelola SPR banyak yang belum memahami data satu persatu sapi karena 134 sapi berbeda - beda pemiliknya, selain itu adanya pandemi covid 19 sangat mempengaruhi dalam menurunya pemasaran dan penjualan sapi. Hal ini dikarenakan adanya pembatasan pengunjung atau pembeli sapi untuk mengunjungi peternakan SPR Mega Jaya. Data yang kami dapatkan rata-rata hasil penjualan sapi setiap tahunnya sebelum pandemi covid 19 mencapai $40 \%-50 \%$, sedangkan ketika pandemi covid 19 mengalami penurunan untuk tahun 2020 hanya mencapai $20 \%$.

2. Pemberdayaan Peternak melalui Digitalisasi Barcode Sapi

Adanya kelompok Sekolah Peternak Rakyat (SPR)_Mega Jaya di Dusun Ngantru Desa Sekaran Kecamatan Kasiman merupakan asset Sumber daya Manusia perlu kita apresiasi dan kita damping untuk diberdayakan. Bagaimana tidak masayarakat yang tinggal didusun terpencil yang ada didalam kawasan hutan jati mampu memanfaatkan sumber daya alam yang ada secara kreatif dan inovatif untuk membuat kelompok peternak sapi yang mana untuk penggemukannya memanfaatkan lahan Kawasan hutan utuk ditanami rumput gajahdan jagung yang nantinya akan digunakan sebagai pakan ternak dan juga kotoran sapi sebagi bio gas yang akan di gunakan untuk kebutuhan sehari-hari masyarakat Dusun Ngantru. SPR Mega Jaya yang ada di Dusun Ngantru Desa Sekaran Kecamatan Kasiman merupakan satu dari 3 SPR yang ada di Bojonegoro, dimana hal tersebut merupakan kegiatan nasional yang dikembangkan oleh IPB untuk penggemukan dan pengembangbiakan sapi. Pada Tahun 
2017 SPR Mega Jaya mendapatkan bantuan sapi sebanyak 134 sapi yang terdiri dari 4 Pejantan dan 130 betina. Kendati demikian pada masa pandemi covid 19 menjadi problem tersendiri untuk kelompok SPR Mega Jaya diantaranya masalah penjualan dan pemasaran sapi yang menurun, Data sapi yang masih manual dan tidak akurat serta informasi sapi kepada para pembeli yang terkena pembantasan kunjungan. Harapan dari kelompok SPR Mega jaya adalah bagaimana menyelesaikan problem tersebut sehingga mampu memasarkan sapi dengan lebih efektif, efisian dan memberikan informasi data secara cepat, tepat dan akurat kepada pengunjung maupun customer yang berkunjung ke SPR Mega Jaya. Rata - rata mata pencaharian masyarakat Dusun Ngantru selain tergabung dalam kelompok SPR Mega Jaya Dusun Ngantru juga memiliki pekerjaan lainnya seperti bekerja sebagai Petani, pedagang, dan penjahit sesuai dengan data table berikut $:^{11}$

Tabel 1.1 Jumlah Mata pencaharian

\begin{tabular}{|c|l|c|}
\hline No. & \multicolumn{1}{|c|}{ EKONOMI } & JUMLAH \\
\hline 1. & Petani & 145 \\
\hline 2. & Pedagang & 11 \\
\hline 3. & Peternak & 63 \\
\hline 4. & Penjahit & 9 \\
\hline
\end{tabular}

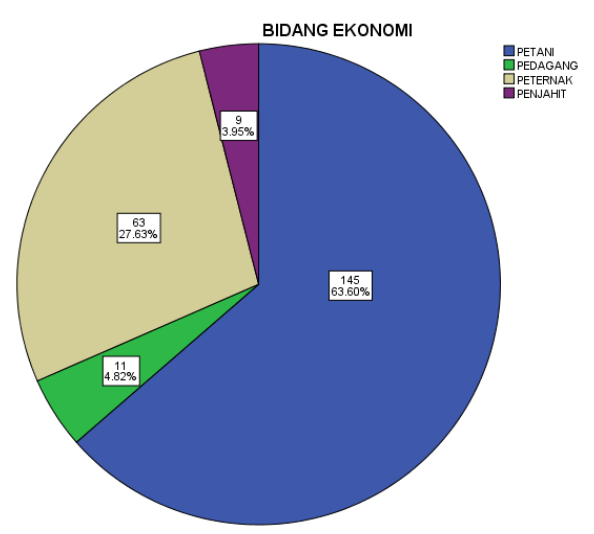

Gambar 1.1 Diagram Ekonomi

Dari tabel di atas diketahui jumlah asset ekonomi yang ada di dusun Ngantru yaitu Petani dengan jumlah 145, Pedagang dengan jumlah 11,Peternak yang tergabung dalam SPR dengan jumlah 63, dan Penjahit dengan jumlah 9. Dari tabel dan diagram lingkaran tersebut terlihat jumlah yang terbanyak yaitu Petani sedangkan yang sedikit yaitu Penjahit.

Berdasarkan problem kelompok SPR mega jaya yang dihadapi dan asset berupa SDM maupun SDA yang dimiliki, maka peneliti tertarik untuk memberikan solusi alternatif dan pendampingan terkait permasalahan yang dihadapi melalui pendambingan program digitalisasi data sapi dengan "Barcode" sapi.

Barcode (kode batang) merupakan sekumpulan data optik yang diperuntukkan untuk dibaca mesin. Barcode diperoleh dari mengumpulkan data-data dalam lebar (garis) dan spasi garis parallel yang disebut sebagai kode batang atau simbologi linier atau 1D (1 dimensi) kemudian data-data tersebut .diScan. ${ }^{12}$ Cara pe Pendampingan pembuatan barcode sapi ini bertujuan untuk memudahkan pengunjung yang

\footnotetext{
${ }^{11}$ Darwanto, kepala Dusun Ngantru, wawancara mata pencarian, 6 maret 2021

${ }^{12}$ Yudha Yudhanto, "Sejarah Teknologi Barcode”, Ilmu Komputer.Com, (2003-2007), 3.
} 
berkunjung ke Sekolah Peternak Rakyat (SPR) dengan membuat barcode yang beisi tentang data-data sapi di Sekolah Peternak Rakyat (SPR) mega jaya yang meliputi data jenis sapi, usia sapi, reproduksi sapi, keturunan sapi, berat sapi, nama pemilik dan alamat pemilik kemudian memasangkannya di masing-masing sapi tersebut, sehingga memudahkan pengunjung mendapatkan data-data tentang sapi meskipun pemilik sapi itu tidak berada di lokasi.

Gambar 1.2

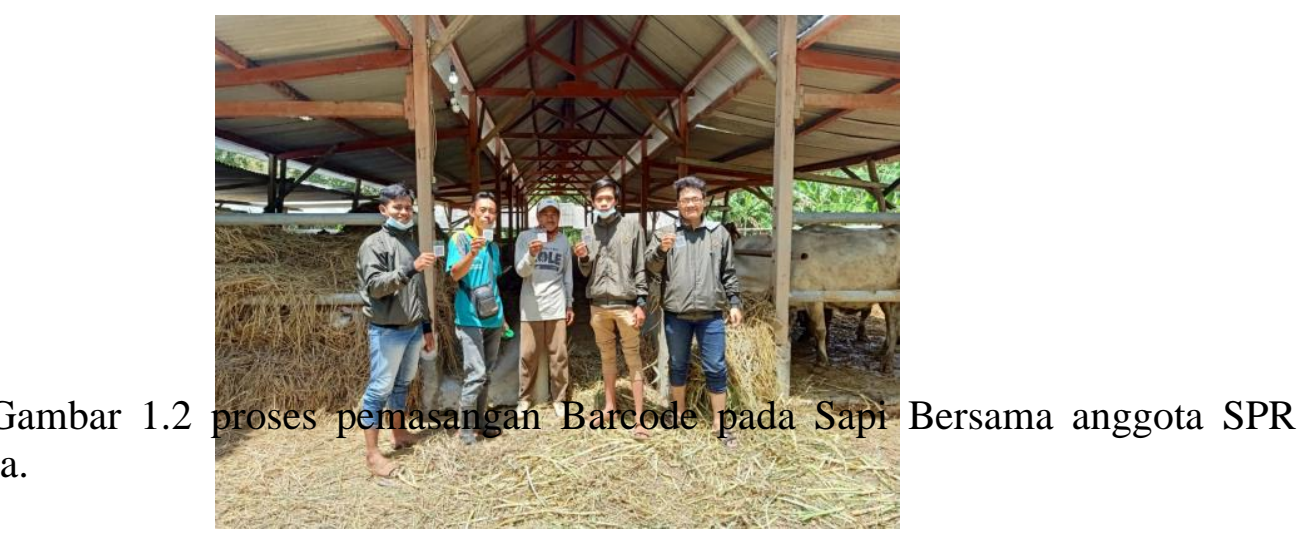
Mega Jaya.

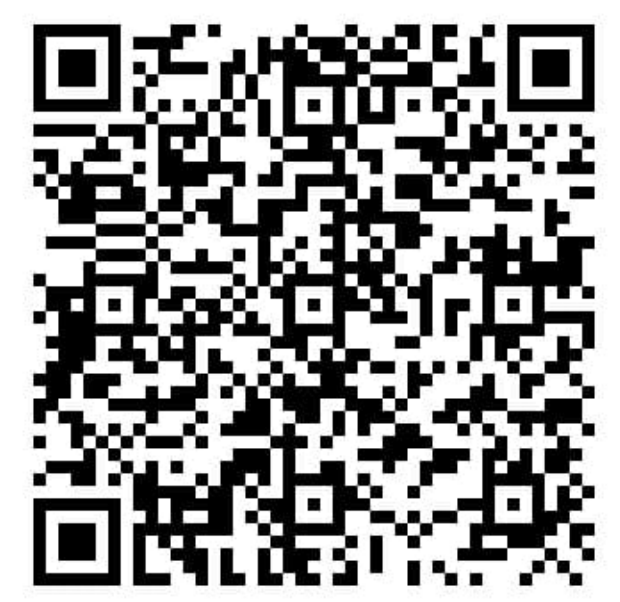

Gambar 1.3 Bentuk Barcode Sapi

Program pendampingan ini dilaksanakan dengan mengumpulkan data-data seluruh sapi terlebih dahulu yang meliputi jenis sapi, usia sapi, reproduksi sapi, keturunan sapi, berat sapi, nama pemilik dan alamat pemilik Sapi. . Sapi tersebut adalah sapi - sapi yang berada dan dikelola di SPR Mega Jaya. Kegiatan pendataan tersebut dibantu oleh bendahara SPR pak Lamuji dan beberapa anggota dari SPR Mega Jaya Dusun Ngantru. Setelah data terkumpul maka akan dimasukan ke dalam sistem barcode dan dibuatkan Akun. Setelah itu baru mulai proses pembuatan dan mencetak barcode. Akhirnya pada tanggal 28 Maret 2021 dilakukan pemasangan barcode dengan cara mengkalungkan di leher sapi bersama pemilik sapi-sapi dan Bapak Kepala Dusun Ngantru. 


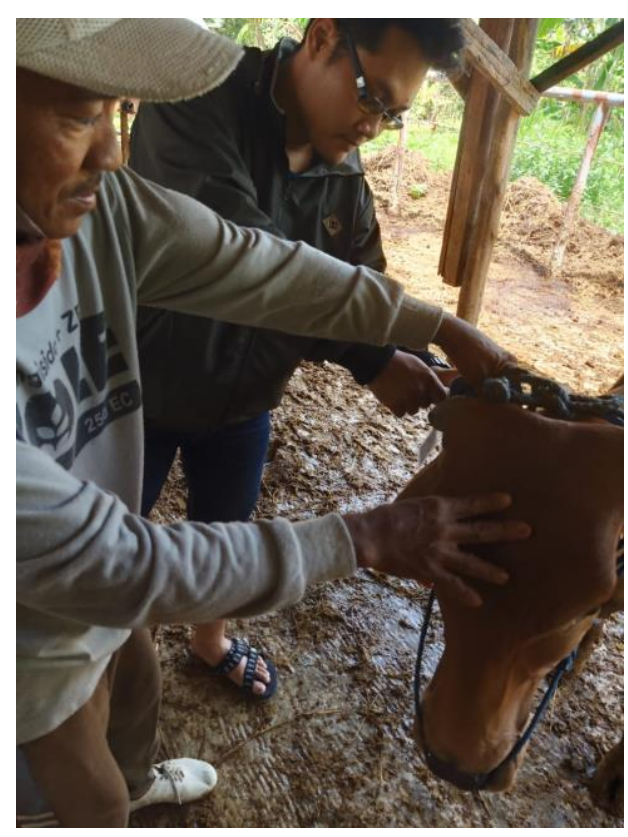

Gambar 1.4 Pemasangan barcode pada leher Sapi.

Hasil dari program pendampingan ini adalah pertama calon pembeli sapi ataupun pengelola sapi di kelompok ternak SPR Mega Jaya dapat dengan mudah mengetahui data sapi - sapi yang ada tanpa harus menemui pemilik sapi. kedua calon pembeli akan mendapatkan inforamasi yang akurat tentang biodata sapi yang akan di beli. Ketiga meningkatnya penjualan sapi kelompok peternak SPR Mega jaya dimasa pandemi dibandingkan sebelum menggunakan sistem Barcode. ${ }^{13}$ Keempat meningkatkan pola manajemen data dan pemasaran sapi berbasis IT. Kelima meningkatkan kepedulian pemuda karang taruna Dusun Ngantru untuk menjadi kader \& relawan IT Kelompok ternak SPR Mega Jaya.

3. Keterlibatan Pemuda Karang Taruna Dalam Pendampingan digitalisasi barcode sapi

Dalam sebuah program pemberdayaan masyarakat salah satu hal yang terpenting adalah partisipasi masyarakat. ${ }^{14}$ Anggota kelompok SPR Mega Jaya awal terbentuk jumlah anggotanya kurang lebih 63 orang dan saat ini jumlah anggota SPR Mega Jaya menurun menjadi 27 orang, hal ini dikarenakan masyarakat memilih untuk mengundurkan diri dan menggemukan sapi di rumah masing-masing.

Mekanisme pembagian tugas seperti pemberian pakan, pemeliharaan hewan ternak dan pemasaran sapi didasarkan pada kesadaran dan rasa saling percaya antar anggota. Akan tetapi dalam penggunaan digitalisasi data sapi melalui barcode membutuhkan pendampingan dan peran serta dari pemuda karang taruna Dusun Ngantru sebagai operator dari sistem barcode dan pengembangan sistem barcode sapi ke dalam WEB SPR mega jaya Dusun Ngantru. Hal ini karena 27 anggota yang tergabung dalam SPR Mega Jaya berusia 40 - 65 Th yang rata-rata merupakan lulusan SD, sehingga dalam penggunaan sistem IT masih sangat minim.

Untuk itu dalam rangka mengembangkan program pemberdayaan peternak SPR melalui digitalisasi Barcode sapi, kami membentuk kader IT dari pemuda karang taruna Dusun Ngantru yang mana dengan tujuan untuk melanjutkan pendampingan kepada anggota SPR mega jaya dan mengembangkan digitalisasi Barcode pada website sehingga akan lebih

\footnotetext{
${ }^{13}$ Lamuji, Bendahara SPR Mega Jaya,Wawancara 31 Maret 2021.

${ }^{14}$ Sunartiningsih, A (Ed). 2004. Strategi Pemberdayaan MasyarakatYogyakarta: Aditya Media
} 
memudahakan para pembeli untuk mendapatkan info Sapi pada kelompok SPR mega jaya tanpa harus datang secarang langsung ke Dusun Ngantru.

Salah satu bentuk pengkaderan pemuda karang taruna untuk menjadi tim IT adalah dengan melalukan pendampingan IT yang meliputi pendampingan penggoperasian sistem barcode, pembuatan Website dan desain grafis.
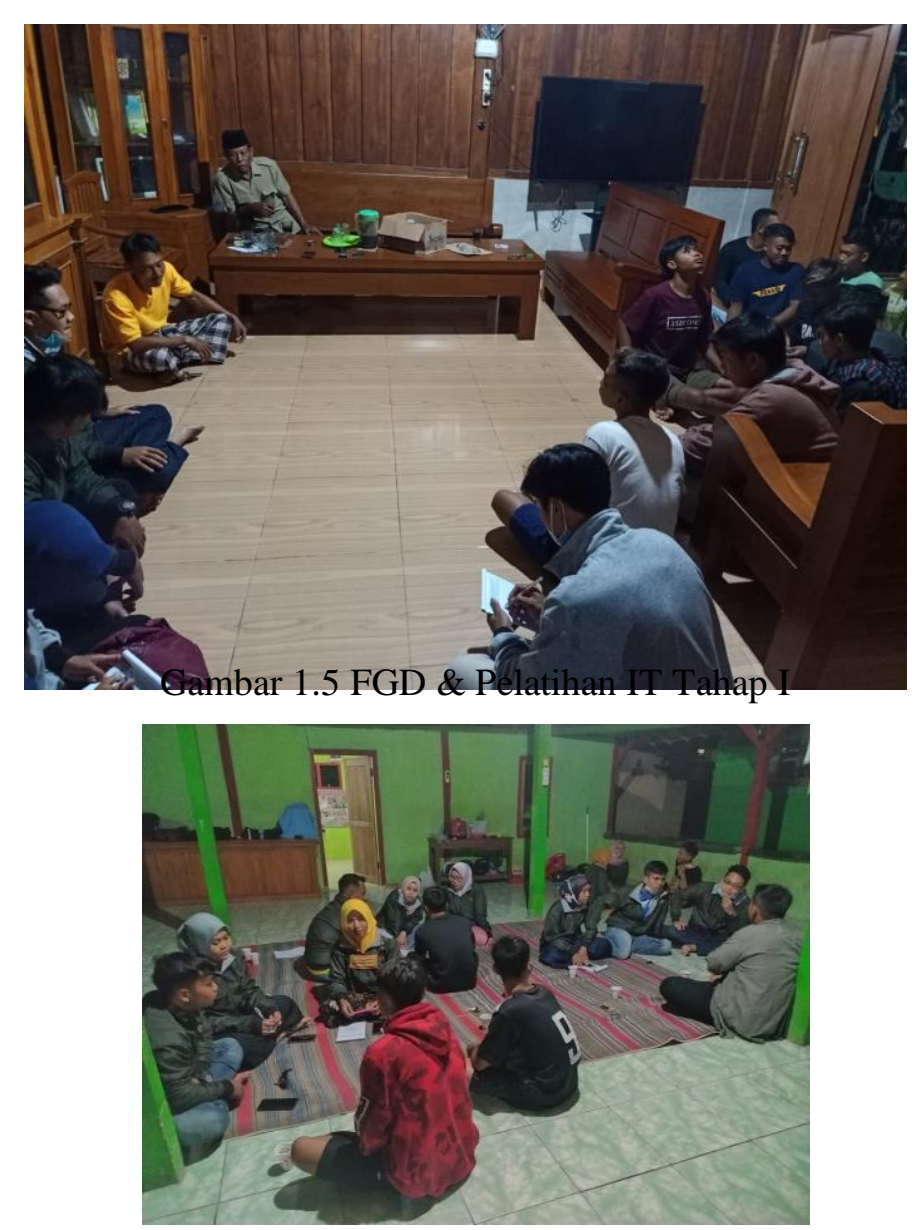

Gambar 1.6 Pelatihan IT barcode Tahap II

4. Dampak Pemberdayaan melalui Barcode Sapi untuk SPR Mega Jaya 
Meskipun kegiatan pendampingan dan pemberdayaan kelompok ternak SPR mega jaya melalui digitalisasi barcode sapi dilakukan ditengah pandemic covid 19 banyak dampak yang dirasakan oleh masyarakat Dusun Ngantru khususnya kelompok anggota ternak SPR Mega Jaya Dusun Ngantru diantaranya kemudahan pembeli dalam mendapatkan info tentang data data sapi yang akan di beli tanpa harus bertemu atau mencari anggota pemilik sapi ternak SPR Mega Jaya. Selain itu membantu dalam meningkatkan penjualan pemasaran sapi dimasa pandemi covid 19 melalui website SPR Mega jaya Dusun Ngantru sehingga menarik pengunjung atau pembeli. Selain itu dampak dari pendampingan melalui digitalisasi dengan barcode mampu memberikan pengetahuan baru tentang pola manajemen data dan pemasaran sapi berbasis teknologi (melek IT) sehingga informasi tentang kelompok peternak SPR Mega Jaya Dusun Ngantru mampu diakses melalui website ataupun media sosial.

Tabel 3.2 rekap kuisioner barcode

Berdasarkan penjabaran dari table diatas, nilai partisipasi masyarakat terhadap program pelatihan barcode sapi dan pelatihan membuat barcode dapat diuraikan sebagai berikut :

Pada pernyataan nomor 1 yakni pelatihan ini perlu dilakukan nilai partisipasi masyarakat nya yang sangat setuju ada 12 orang setuju 13 orang biasa saja 3 orang

\begin{tabular}{|c|c|c|c|c|c|c|}
\hline \multirow[t]{2}{*}{ No. } & \multirow{2}{*}{$\begin{array}{c}\text { Pertanyaan } \\
\text { Nomor }\end{array}$} & \multicolumn{5}{|c|}{ Jumlah Partisipasi } \\
\hline & & $\begin{array}{l}\text { Sangat } \\
\text { setuju }\end{array}$ & Setuju & $\begin{array}{l}\text { Biasa } \\
\text { saja }\end{array}$ & $\begin{array}{l}\text { Tidak } \\
\text { setuju }\end{array}$ & $\begin{array}{l}\text { Sangat } \\
\text { tidak } \\
\text { setuju }\end{array}$ \\
\hline 1 & $\begin{array}{l}\text { Pendampingan } \\
\text { Barcode ini } \\
\text { perlu dilakukan. }\end{array}$ & $45 \%$ & $45 \%$ & $5 \%$ & $5 \%$ & $0 \%$ \\
\hline 2 & $\begin{array}{l}\text { Pelatihan ini } \\
\text { mendatangkan } \\
\text { narasumber } \\
\text { yang sesuai di } \\
\text { bidangnya. }\end{array}$ & $50 \%$ & $40 \%$ & $10 \%$ & $0 \%$ & $0 \%$ \\
\hline 3 & $\begin{array}{l}\text { Pelatihan ini } \\
\text { cocok dilakukan } \\
\text { saat pandemi } \\
\text { Covid- } 19 .\end{array}$ & $40 \%$ & $50 \%$ & $5 \%$ & $5 \%$ & $0 \%$ \\
\hline 4 & $\begin{array}{l}\text { Saya menjadi } \\
\text { tahu tentang } \\
\text { cara membuat } \\
\text { barcode }\end{array}$ & $45 \%$ & $45 \%$ & $5 \%$ & $5 \%$ & $0 \%$ \\
\hline 5 & $\begin{array}{l}\text { Pelatihan } \\
\text { berlangsung } \\
\text { dengan menarik. }\end{array}$ & $40 \%$ & $40 \%$ & $15 \%$ & $5 \%$ & $0 \%$ \\
\hline 6 & $\begin{array}{l}\text { Pelatihan ini } \\
\text { baru pertama } \\
\text { kali dilakukan di } \\
\text { desa Sekaran. }\end{array}$ & $45 \%$ & $40 \%$ & $10 \%$ & $5 \%$ & $0 \%$ \\
\hline 7 & $\begin{array}{l}\text { Narasumber } \\
\text { menjelaskan } \\
\text { materi secara } \\
\text { detail dan jelas. }\end{array}$ & $50 \%$ & $40 \%$ & $10 \%$ & $0 \%$ & $0 \%$ \\
\hline
\end{tabular}

Pada pernyataan 2 yakni pelatihan ini mendatangkan narasumber yang sesuai di bidangnya nilai partisipasi masyarakatnya yang sangat setuju ada 13 orang setuju 10 orang biasa saja 5 orang 
Pada pernyataan nomor 3 yakni pelatihan ini cocok dilakukan saat pandemi covid 19 nilai partisipasi masyarakat nya yang sangat setuju ada 10 orang setuju 13 orang biasa saja 3 orang

Pada pernyataan nomor 4 yakni saya menjadi tahu tentang cara membuat barcode nilai partisipasi masyarakatnya sangat setuju 12 orang setuju 12 orang biasa saja 3 orang

Pada pernyataan nomor 5 yakni pelatihan berlangsung dengan menarik nilai partisipasi masyarakat nya yang sangat setuju ada 10 orang setuju 10 orang biasa saja 3 orang

Pada pernyataan nomor 6 nilai yakni pelatihan Ini baru pertama kali dilakukan di desa Sekaran nilai partisipasi masyarakat nya yang sangat setuju ada 12 orang setuju 10 orang biasa saja 3 orang

Pada pernyataan nomor 7 yakni narasumber menjelaskan materi secara detail dan jelas nilai partisipasi masyarakat nya yang sangat setuju 13 orang setuju 10 orang biasa saja 3 orang. ${ }^{15}$

\section{SIMPULAN}

Melalui kegiatan program pendampingan digitalisasi data sapi dengan Barcode maka dapat diketahui bahwa program digitalisasi dengan barcode memiliki dampak dalam peningkatan ekonomi kelompok ternak SPR Mega Jaya Dusun Ngantru Kecamatan Kasiman. Hasil dari digitalisasi dengan barcode yang pertama adalah meningkatnya penjualan sapi kelompok peternak SPR Mega jaya dimasa pandemi dibandingkan sebelum menggunakan sistem Barcode. Yang kedua memudahkan pengelola kelompok ternak untuk memberikan informasi data sapi secara cepat dan akurat kepada calon pembeli dan pengunjung. Yang Ketiga meningkatkan kepedulian pemuda karang taruna Dusun Ngantru untuk menjadi kader \& relawan IT Kelompok ternak SPR Mega Jaya, dan yang keempat meningkatkan pola manajemen data dan pemasaran sapi berbasis IT. Peningkatan pendapatan dan penjualan sapi kelompok ternak SPR Mega Jaya Dusun Ngantru pada masa pandemi menjadi salah satu indicator keberhasilan program.

\section{DAFTAR PUSTAKA}

Chika Riyanti dan Santoso Tri Raharjo, (2021), “Asset Based Community Development dalam Program Corporate Social Responsibility (CSR), Jurnal Kolaborasi Resolusi Konflik, No. 1, Vol. 3, 116.

Christopher Dureau, (2013) Pembaru dan Kekuatan Lokal Untuk Pembangunan, Australian Community Development and Civil Society Strengthening Scheme (ACCES) Tahap II, 96-97.

Kartika Tribuana Dewi,(2013), Kemitraan Masyarakat Peternak Sapi Perah Dengan Kud "Batu" Dalam Meningkatkan Ekonomi Masyarakat Peternak Sapi Perah, Jurnal Administrasi Publik, Vol 1, No. 4.

LPPM IPB, "SPR Bojonegoro", httpp;//LPPM.IPB.ac.id/?page_id=8100, diakses pada tanggal 7 April 2021 pukul 22.50 wib.

Nurul Mahmudah. (2018). "Pemberdayaan Pada Anak-Anak Gang Dolly di SMA Artantika dengan Metode Asset Based Community Development", Madani, No.1, Vol. 1, 17-29.

Sawitri, A. P., Ajiningrum, P. S., \& Suhardiyah, M. (2018). Peningkatan Ekonomi Peternak Sapi Perah dan Masyarakat Desa Melalui Diversifikasi Produk Olahan Dengan Bahan Baku Susu Sapi. JPM (Jurnal Pemberdayaan Masyarakat), 3(2), 272 - 278

\footnotetext{
${ }^{15}$ Penyebaran angket pada warga Dusun Ngantru
} 
Sunartiningsih, A (Ed). (2004). Strategi Pemberdayaan MasyarakatYogyakarta: Aditya Media Tim Penyusun KKN ABCD UNUGIRI Bojonegoro, (2021) Buku Pedoman Pelaksanaan KKN Universitas Nahdlatul Ulama Sunan Giri Bojonegoro, (Bojonegoro: LPPM UNUGIRI Bojonegoro), 22.

Yudha Yudhanto, "Sejarah Teknologi Barcode", Ilmu Komputer.Com, (2003-2007), 3. 